\title{
Francis Gingras, Lumières sur le Moyen Âge: les 'Perceval' concurrents de la Bibliothèque universelle des romans
}

\section{Maria Colombo Timelli}

\section{(2) OpenEdition Journals}

Édition électronique

URL : http://journals.openedition.org/studifrancesi/3643

DOI : $10.4000 /$ studifrancesi.3643

ISSN : 2427-5856

Éditeur

Rosenberg \& Sellier

\section{Édition imprimée}

Date de publication : 1 décembre 2012

Pagination : 542

ISSN : 0039-2944

\section{Référence électronique}

Maria Colombo Timelli, «Francis Gingras, Lumières sur le Moyen Âge: les 'Perceval' concurrents de la Bibliothèque universelle des romans », Studi Francesi [En ligne], 168 (LVI | III) | 2012, mis en ligne le 30 novembre 2015, consulté le 05 mars 2021. URL : http://journals.openedition.org/studifrancesi/3643 ; DOI : https://doi.org/10.4000/studifrancesi.3643

Ce document a été généré automatiquement le 5 mars 2021.

\section{cc) (†) $\odot$}

Studi Francesi è distribuita con Licenza Creative Commons Attribuzione - Non commerciale - Non opere derivate 4.0 Internazionale. 
Francis Gingras, Lumières sur le Moyen Âge: les 'Perceval' concurrents de la Bibliothèque universelle des romans

Maria Colombo Timelli 


\section{RÉFÉRENCE}

FRANCIS GINGRAS, Lumières sur le Moyen Âge: les 'Perceval' concurrents de la Bibliothèque universelle des romans, «Revue des Langues Romanes», CXV, 2011 (Le Moyen Âge des imaginations savantes), pp. 49-72.

Ce bel article concerne la réception du dernier roman de Chrétien de Troyes du XII au XVIII ${ }^{e}$ siècle. F.G. examine d'abord la transmission du Conte du Graal dans un certain nombre de manuscrits qui contiennent aussi d'autres textes du 'cycle' (Continuations et/ ou prologues fictifs: Elucidation, Bliocadran), pour passer ensuite à l'adaptation en prose publiée à Paris en 1530. On sait que les $\mathrm{XVI}^{\mathrm{e}}$ et $\mathrm{XVII}^{\mathrm{e}}$ siècles, avec les remarquables exceptions des bibliophiles et érudits que furent Claude Fauchet, le Président Bouhier, ou encore La Croix du Maine et Du Verdier, ont ignoré tant le nom de Chrétien que ses œuvres, ce qui permet d'apprécier dans sa juste lumière la publication, dans la Bibliothèque universelle des romans, de la «miniature» de tous ses romans lorsque cette collection était encore dirigée par le marquis de Paulmy. Le Perceval, quant à lui, eut droit même à deux synthèses, tirées de la prose de 1530 et publiées à 8 années de distance: l'une en novembre 1775, sortie de la plume de Paulmy, l'autre en novembre 1783, due au comte de Tressan. F.G. montre bien la dualité qui marque ces deux «extraits», reflet d'une double réception, érudite la première, plus imaginative la seconde. 